Piotr Możyłowski

Wyższa Szkoła Nauk Społecznych

i Technicznych w Radomiu

\title{
Prawno-administracyjne bariery prowadzenia dzialalności gospodarczej w Polsce w świetle opinii przedsiębiorców oraz raportów Doing Business
}

\author{
Legal and administrative barriers to business in Poland in the light \\ of the opinions of entrepreneurs and the 'Doing Business' reports
}

\begin{abstract}
Streszczenie
Jednym z czynników warunkujących konkurencyjność przedsiębiorstw i innych podatników oraz niezakłócony przebieg jej rozwoju jest bezpieczeństwo prawne podmiotów prowadzących działalność gospodarczą. Wyraża się ono m.in. w zachowaniu wymogu stabilności i spójności opodatkowania. Ustawodawca musi zapewnić podatnikowi możliwość poznania jego uprawnień i obowiązków podatkowych, zanim staną się one obowiązującymi i wymagalnymi. Podmioty objęte podatkiem muszą być pewne, że trwałość obowiązywania prawa podatkowego podlega ochronie, która stanowić będzie jednocześnie ochronę ich interesów. Stąd też wynikać będzie podstawowa zasada stabilności obowiązywania prawa, która odnosi się nie tylko do prawa podatkowego, ale także do innych dziedzin prawa. Przepisy prawa, regulujące uprawnienia i obowiązki, zależne są przede wszystkim od zmieniających się warunków ustrojowych, społecznych i ekonomicznych. W niniejszym artykule podjęto próbę wskazania najważniejszych barier prowadzenia działalności gospodarczej wymienianych przez przedsiębiorców, jak i inne instytucje, w tym Bank Światowy. Podjęto zarazem próbę podsumowania ocen, jakie otrzymuje polskie ustawodawstwo podatkowe tak ze strony ekspertów Banku Światowego, jak i - a może przede wszystkim - ze strony polskich przedsiębiorców. Coroczne raporty Banku Światowego Doing Business oraz badania ankietowe przedsiębiorców ukazują stan polskiego ustawodawstwa w zakresie opodatkowania, co stanowi doskonałe źródło do wskazania słabych stron sytemu podatkowego oraz możliwości jego poprawy. W opracowaniu tym skupiono się w szczególności na systemie podatkowym jako tym, który może być instrumentem wpływającym pozytywnie lub negatywnie na gospodarkę oraz na rozwój przedsiębiorczości.
\end{abstract}

\begin{abstract}
One of the factors improving the competitiveness of factories and small business is, among others, legal security. This is represented by stability and cohesiveness of the tax system. Legislature must ensure that taxpayers are aware of their rights and duties, before tax is applicable. Entities covered by the tax system must be certain that the stability of the tax law is protected, and that their interests are secured as well. Hence, the result should take form of a basic principle of stability of law, which applies not only to tax regulations, but also to other legal areas. Law governing the powers and duties is primarily dependent on the changing political, social and economic situations. This article attempts to identify the most important barriers, indicated by businessmen, and various institutions, including
\end{abstract}


the World Bank. The article also contains a summary of ratings received by the Polish tax legislation system, provided by World Bank experts, and, perhaps more importantly, by Polish entrepreneurs. Annual reports of the World Bank, and the 'Doing Business' surveys present the situation of Polish entrepreneurs in the field of tax legislation and may serve as an excellent source for identifying weaknesses in the tax system and possibilities for its improvement. This study focuses in particular on the tax system, as the one which can positively or negatively affect the economy, and development of entrepreneurship.

Słowa kluczowe: bariery podatkowe; działalność gospodarcza; opinie; raport; system podatkowy

Key words: tax barriers; economic activity; review; report; tax system

\section{Wprowadzenie}

Jednym z czynników warunkujących konkurencyjność przedsiębiorstw i innych podatników oraz niezakłócony przebieg tego rozwoju jest bezpieczeństwo prawne podmiotów prowadzących działalność gospodarczą. Wyraża się ono m.in. w zachowaniu wymogu stabilności i spójności opodatkowania. Ustawodawca musi zapewnić podatnikowi możliwość poznania jego uprawnień i obowiązków podatkowych, zanim staną się one obowiązującymi i wymagalnymi. Podmioty objęte podatkiem muszą być pewne, że trwałość obowiązywania prawa podatkowego podlega ochronie, która stanowić będzie jednocześnie ochronę ich interesów. Stąd też wynikać będzie podstawowa zasada stabilności obowiązywania prawa, która odnosi się nie tylko do prawa podatkowego, ale także do innych dziedzin prawa. Przepisy prawa, regulujące uprawnienia i obowiązki, zależne są przede wszystkim od zmieniających się warunków ustrojowych, społecznych i ekonomicznych.

O reformie i o tym, jak powinien być zbudowany system podatkowy, dyskutuje się w Polsce od lat, jednakże dyskusja ta nie przyniosła jak dotąd pożądanych efektów. Co jakiś czas jest mowa o tym, jak ma wyglądać system podatkowy i jak ma być zbudowany (z ilu podatków, jakie znaczenie mają mieć poszczególne podatki). Jednakże nie zawsze $w$ tych debatach przedstawia się kwestię, w jakim kierunku powinny iść przeobrażenia obecnie istniejącego systemu podatkowego (np. jak ukształtować system, aby uległ ograniczeniu stopień jego fiskalizmu, a z drugiej strony zapewnić wystarczające dochody na realizację funkcji państwa) (Szołno-Koguc, 2001: 202; Szczodrowski, 2003: 97). Można stwierdzić, iż do dziś nie określono, jakie funkcje powinien spełniać system podatkowy w Polsce. Czy ma to być tylko funkcja fiskalna, czy może redystrybucyjna albo gospodarcza?

Analizując historię istnienia polskiego systemu podatkowego, na myśl przychodzą dwie przyczyny wpływające na taką sytuację, a mianowicie zmiana ustroju gospodarczego z gospodarki centralnie planowanej na gospodarkę rynkową oraz członkostwo Polski w Unii Europejskiej. Oczywiście należy mieć na uwadze fakt, iż nie tylko polskie prawo podatkowe uległo znacznemu skomplikowaniu. To właśnie wstąpienie Polski w struktury Unii Europejskiej wywarło znaczący wpływ na obecny kształt przepisów podatkowych. Niestety, trzeba w tym miejscu wskazać jednoznacznie, iż pomimo niekwestionowanych zalet samej UE, jest to Wspólnota bardzo zbiurokratyzowana, tworząca dużą liczbę przepisów regulujących funkcjonowanie życia (w tym właśnie prawo podatkowe).

To, czy stabilność prawa podatkowego, przyjętego w warunkach zmiany ustroju politycznego i gospodarczego będzie trwała, zależy od wartości materialnej i jakości legislacyjnej tego prawa. Wartość materialną ma prawo podatkowe wyrażające racjonalną i spójną koncepcję systemu podatkowego (Arent, 2007: 219). Zaś miarą jakości legislacyjnej prawa podatkowego jest takie jego opracowanie, uchwalenie i ogłoszenie, aby zachować zasady przyzwoitej legislacji. Jeśli nowe prawo jest miernej jakości legislacyjnej, to konieczne staje się dokonywanie 
w nim zmian. Jeżeli zaś zmiany te będą mieć charakter doraźny, incydentalny czy przypadkowy i okazjonalny, to ich efektem będzie powstanie prawa podatkowego, opartego na licznych aktach normatywnych.

Warto w tym miejscu zaznaczyć, iż obecnie kwestie podatkowe obrosły w liczne nieporozumienia, przeinaczenia i stereotypy. Wygłaszane na ten temat poglądy są często wynikiem nie tyle obiektywnej wiedzy, ile czasami gry interesów. Dlatego autor w tym miejscu pragnie zaznaczyć, iż czytelnik może w pewnych częściach pracy odnaleźć odmienne opinie od tych prezentowanych przez ośrodki badawcze. Będą to jednak opinie wynikające ze zdobytych doświadczeń zawodowych autora jako pracownika urzędu skarbowego. W niniejszym artykule podjęto próbę wskazania najważniejszych barier w prowadzeniu działalności gospodarczej wymienianych przez przedsiębiorców, jak i inne instytucje, w tym Bank Światowy. W opracowaniu skupiono się jednak w szczególności na systemie podatkowym jako tym, który może być instrumentem wpływającym pozytywnie lub negatywnie na gospodarkę oraz na rozwój przedsiębiorczości. I to teraz, w dobie kryzysu gospodarczego.

\section{System podatkowy w rankingach Doing Business 2007-2011}

Polska, jak wiele innych krajów Europy i świata, jest poddawana ciągłym ocenom. Ocen tych dokonują nie tylko zrzeszenia przedsiębiorców, ale także organizacje międzynarodowe. Jedną z instytucji dokonujących przeglądu i zarazem oceny polskiej gospodarki jest Bank Światowy (coroczne raporty Doing Business). W tabeli 1 przedstawiono pozycję Polski pod względem warunków prowadzenia biznesu w rankingu Banku Światowego Doing Business.

Dane przedstawione w tabeli 1 wskazują na sfery życia gospodarczego, w których powinny nastąpić zmiany. Osoby pracujące nad nowymi przepisami, regulującymi prowadzenie działalności gospodarczej, powinny jak najszybciej zwrócić na te wyniki uwagę. Refleksja powinna być taka, że należy jak najszybciej likwidować bariery administracyjno-prawne. Analizując poszczególne wskaźniki uwzględnione w raporcie, można zauważyć, że na przestrzeni 5 lat

Tab. 1. Pozycja Polski w rankingach Doing Business 2007-2011

\begin{tabular}{|c|c|c|c|c|c|c|c|c|c|c|c|c|}
\hline \multirow{2}{*}{$\begin{array}{l}\text { Wyszcze- } \\
\text { gólnienie } \\
\text { Doing } \\
\text { Business }\end{array}$} & \multirow{2}{*}{$\begin{array}{c}\text { Liczba } \\
\text { państw } \\
\text { objętych } \\
\text { badaniem }\end{array}$} & \multirow{2}{*}{$\begin{array}{c}\text { Pozycja Polski } \\
\text { w rankingu } \\
\text { dotyczącym } \\
\text { latwości } \\
\text { prowadzenia } \\
\text { działalności } \\
\text { gospodarczej }\end{array}$} & \multicolumn{10}{|c|}{$\begin{array}{c}\text { Pozycja Polski w odniesieniu do } 10 \text { wskaźników } \\
\text { mających wiodące znaczenie dla prowadzenia } \\
\text { dzialalności gospodarczei }\end{array}$} \\
\hline & & & $1 *$ & $2 *$ & $3 *$ & $4 *$ & $5 *$ & 6* & $7 *$ & 8* & 9* & $10 *$ \\
\hline 2007 & 175 & 75 & 114 & 146 & 49 & 86 & 65 & 33 & 71 & 102 & 112 & 85 \\
\hline 2008 & 178 & 74 & 134 & 156 & 81 & 81 & 25 & 33 & 133 & 42 & 68 & 91 \\
\hline 2009 & 181 & 72 & 145 & 157 & 69 & 86 & 27 & 38 & 147 & 41 & 71 & 85 \\
\hline 2010 & 183 & 72 & 117 & 164 & 76 & 88 & 15 & 41 & 151 & 42 & 75 & 85 \\
\hline 2011 & 183 & 63 & 126 & 160 & 82 & 86 & 8 & 46 & 128 & 46 & 87 & 81 \\
\hline
\end{tabular}

$1^{*}$ - rozpoczęcie działalności gospodarczej, $2^{*}$ - zezwolenia i koncesje, głównie na budowę budynków i budowli,

$3^{*}$ - zatrudnianie i zwalnianie pracowników, $4^{*}$ - rejestracja tytułu własności, $5^{\star}$ - uzyskanie kredytu,

$6^{\star}$ - ochrona inwestorów, $7^{\star}$ - podatki, $8^{\star}$ - obrót transgraniczny, 9* - egzekwowanie wykonania postanowień kontraktu, 10* - likwidacja lub upadłość przedsiębiorstw.

Źródło: Raport Banku Światowego Doing Business 2009-2011; Ostaszewski (2010: 213). 
Polska poprawiła swoje wyniki w niektórych aspektach życia gospodarczego, takich jak: łatwość rozpoczynania działalności gospodarczej, uzyskanie kredytu czy obrót transgraniczny. Niewielkie wahania pozycji w rankingu można zauważyć w takich kwestiach, jak rejestrowanie tytułów własności czy likwidacja przedsiębiorstw. Jednak w kwestiach zatrudniania i zwalniania pracowników czy podatkach, czyli tam, gdzie powinna nastąpić zdecydowana poprawa, występują nieznaczne wahania w pozycjach rankingu. Ocena Polski w następnych latach powinna ulec znacznej poprawie, a następnie pewnej stabilizacji. Nie możemy stwarzać też takiej sytuacji, że w jednym roku uzyskujemy dobre wyniki w rankingach, a następnie nie wprowadzamy żadnych pozytywnych zmian. Oczywiście należy pamiętać, że w kategorii obciążeń fiskalnych można uwzględniać nie tylko wysokość samych podatków, ale także częstotliwość, z jaką przedsiębiorcy są zobowiązani je uiszczać oraz całą biurokrację związaną z przygotowaniem odpowiednich formularzy podatkowych (Kalinowska, 2008: 195). Jednak tak niskie oceny to nie skutek wysokich podatków, bo te są dość niskie na tle innych krajów UE, ale czasu związanego z wypełnianiem obowiązków podatkowych czy ich egzekwowaniem. Na rycinie 1 przedstawiono czas potrzebny na przygotowanie dokumentów związanych z podatkiem dochodowym od osób prawnych w Polsce i w wybranych krajach europejskich.

Analizując wskazane raporty, można wysnuć wniosek, że to wysoki stopień skomplikowania przepisów przekłada się na długi czas niezbędny do załatwienia wszelkich formalności związanych z płaceniem podatków i zarazem przyczynia się do hamowania rozwoju przedsiębiorczości oraz rzekomo tworzy niekorzystny klimat dla inwestycji. Poniżej zostanie przedstawiony czas niezbędny, aby wypełnić obowiązki podatkowe w Polsce i w krajach OECD (ryc. 2).

Jak łatwo zauważyć, wypełnianie formalności podatkowych zajmuje w Polsce 175 godzin rocznie. Nie jest to wynik najgorszy, jeśli spojrzymy na takie kraje, jak Włochy, Czechy lub Węgry. Są też opinie, mówiące, że system podatkowy w Niemczech jest bardziej skomplikowany niż w Polsce, gdzie więc u nas tkwi problem? Czyżby Niemcy lepiej znali się na przepisach podatkowych, skoro potrzebują o 70 godzin mniej na wypełnienie dokumentacji podat-

Ryc. 1. Liczba godzin w roku potrzebnych na wypełnienie formalności związanych z podatkiem dochodowym od osób prawnych w Polsce na tle wybranych krajów Europy w 2009 r.

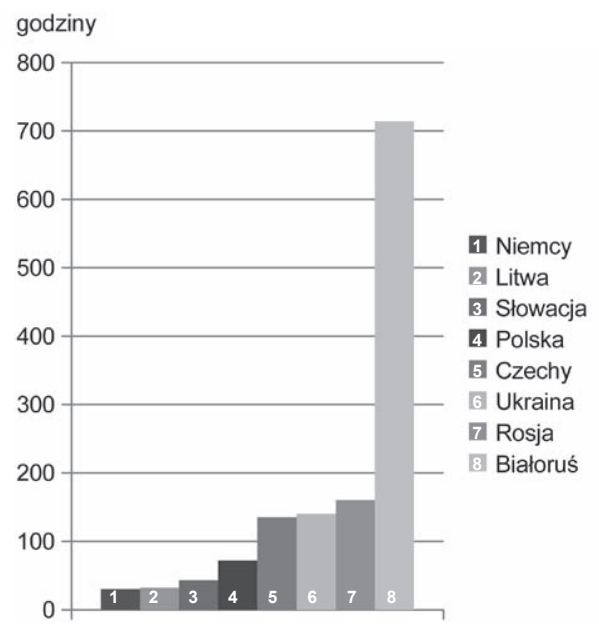

Źródło: Paying Taxes 2010. The globar picture. 
Ryc. 2. Liczba godzin w roku potrzebnych na wypełnienie formalności związanych z obliczaniem i wpłatą podatków w Polsce na tle wybranych krajów Europy w 2009 r.

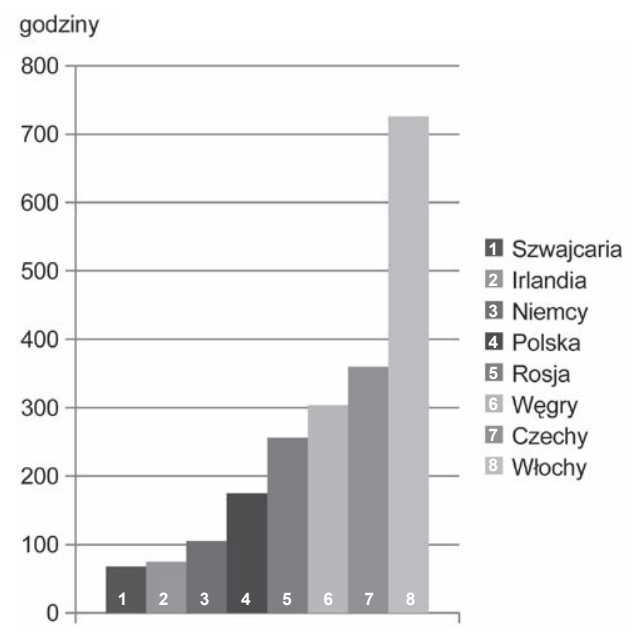

Źródło: Paying Taxes 2010. The globar picture.

kowej? A może niemieccy księgowi i doradcy podatkowi mają większą wiedzę niż polscy? Zapewne wszystko to po trochu. Jednak jest jeszcze jeden aspekt występujący w rozliczeniach. W Niemczech urzędnicy skarbowi mają większe możliwości pomocy podatnikowi niż w Polsce. W naszym kraju pracownik urzędu skarbowego nie ma żadnej możliwości, wręcz jest to zabronione, aby pomóc podatnikowi wypełnić formularz podatkowy. Jedyną możliwością uzyskania większej pomocy ze strony urzędników jest przybycie do urzędu skarbowego w tzw. dni otwarte (soboty), które są organizowane przez Ministerstwo Finansów od kilku lat.

Jednak analizując dokładniej dane zawarte w raportach Banku Światowego, w tym Doing Business 2010, dowiadujemy się, iż w Polsce przedsiębiorca musi dokonać w ciągu roku 40 płatności podatkowych. Jeśli przyjąć w uproszczeniu, że część osób dokonuje płatności w kasie urzędu skarbowego i potrzebuje na to 1 godzinę, to da nam to liczbę dodatkowych 40 godzin. W połączeniu z danymi zawartymi na rycinie 2 daje nam to już sporą liczbę 215 godzin potrzebnych na wypełnienie obowiązków podatkowych. Jak łatwo policzyć, przedsiębiorca, który sam chce zajmować się sprawami podatkowymi, musi na to przeznaczyć bez mała 1,5 miesiąca. W tym czasie mógłby pracować na rzecz swojej firmy i być może dalej ją rozwijać. Oczywiście autor zdaje sobie sprawę, iż niektórzy czytelnicy powiedzą, że może zatrudnić firmę księgową lub doradcę podatkowego ${ }^{1}$. Ale czy o to w tym wszystkim chodzi? Chyba nie.

${ }^{1}$ Doświadczenia zawodowe autora wskazują na taką właśnie praktykę stosowaną przez większość przedsiębiorców. Nie są oni w stanie samodzielnie poprowadzić rozliczeń podatkowych czy wystąpić z wnioskiem o wydanie interpretacji indywidualnej, dlatego muszą korzystać z usług doradców podatkowych i prawników. Ponadto kwestie te są znane bardzo dobrze autorowi z uwagi na fakt, iż pochodzi on z rodziny przedsiębiorców (i to z ponad trzydziestoletnimi tradycjami). Prowadząc działalność gospodarczą opodatkowaną, np. stawką podstawową i obniżoną VAT, a także zwolnioną, przedsiębiorcy nie są w stanie wykonać wszystkich obliczeń samodzielnie. Jeśli jeszcze w działalności pojawi się leasing, kredyt czy factoring, to rozliczenia podatkowe stają się coraz bardziej skomplikowane i pracochłonne. 
Najlepiej pod tym względem wypada Szwajcaria, w której na wypełnienie obowiązków podatkowych potrzeba 68 godzin. Nieźle na tle Polski wypadają: Irlandia (75 godz.), Niemcy (105) i Dania (135). Według raportu gorsi od Polski są np. Hiszpanie, którym potrzeba 603 godzin na wypełnienie obowiązków podatkowych, i Włosi, którzy muszą poświęcić ponad 700 godzin.

Ekonomiści sporządzający przytaczany raport wskazują także na małą transparentność rozwiązań podatkowych, co stwarza szereg okazji „do ucieczki przed podatkami”. Mało czytelne a zarazem skomplikowane przepisy, zachęcają do nadużyć i ukrywania dochodów podatkowych (Kamińska, 2006: 58). Właśnie na niestabilność i skomplikowanie przepisów podatkowych wskazują raporty Banku Światowego.

\section{Podatki i system podatkowy w opinii polskich przedsiębiorców}

Od kilku lat polscy przedsiębiorcy podnoszą problem skomplikowanego systemu podatkowego, szczególnie w części dotyczącej ulg i zwolnień. Od 2001 r. Polska Konfederacja Pracodawców Prywatnych Lewiatan (PKPP Lewiatan) prowadzi badania wśród właścicieli oraz zarządzających małymi i średnimi przedsiębiorstwami poświęcone identyfikacji barier rozwoju MŚP. Lista dziesięciu najważniejszych czynników utrudniających działalność małych i średnich przedsiębiorstw jest od 7 lat niezmienna (zmianie ulega jedynie ich kolejność w rankingu). Z badań Monitoring kondycji sektora MŚP, które Polska Konfederacja Pracodawców Prywatnych Lewiatan prowadziła już po raz kolejny, wynika, że bariery funkcjonowania małych i średnich przedsiębiorstw w Polsce nie zmieniły się (ryc. 3).

Ryc. 3. Najważniejsze bariery w rozwoju MŚP w Polsce*

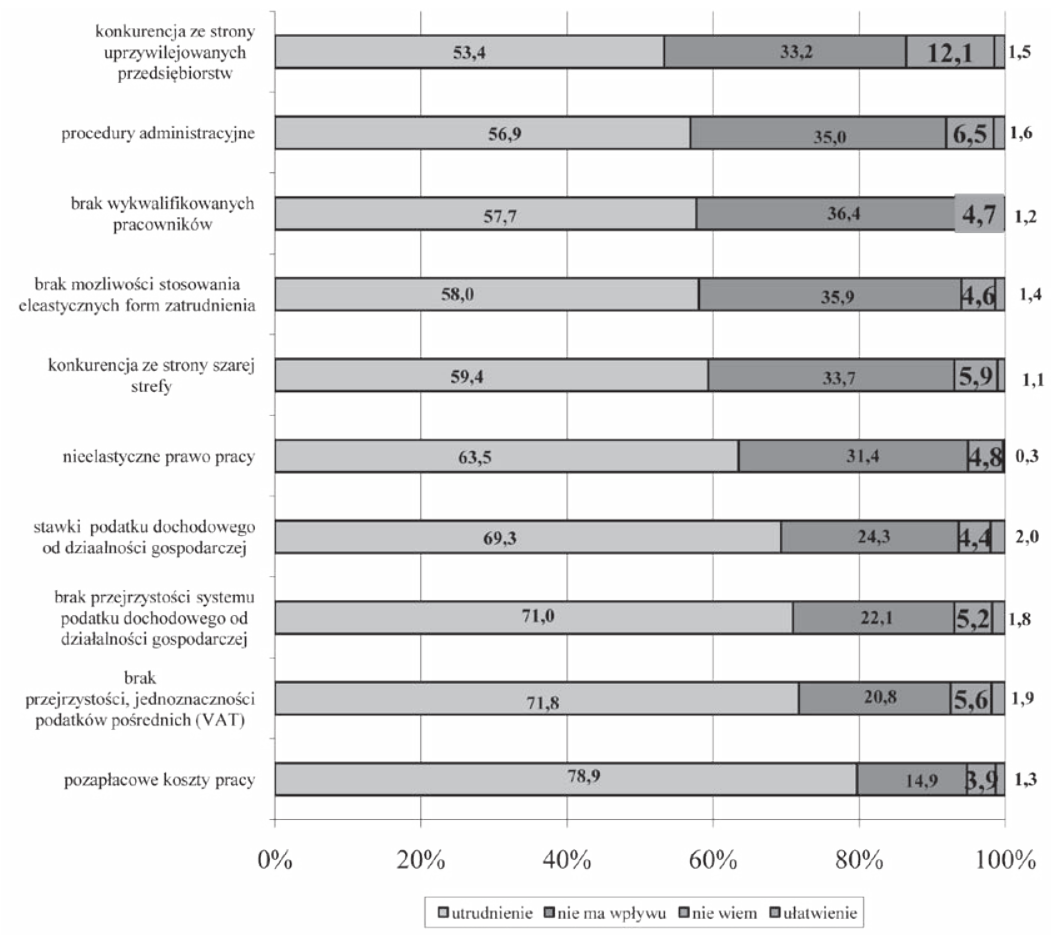

*dane dotyczą badań przeprowadzonych przez PKPP Lewiatan

Źródło: Starczewska-Krzysztoszek (2008: 37). 
Ryc. 4. Bariery administracyjne w prowadzeniu działalności gospodarczej

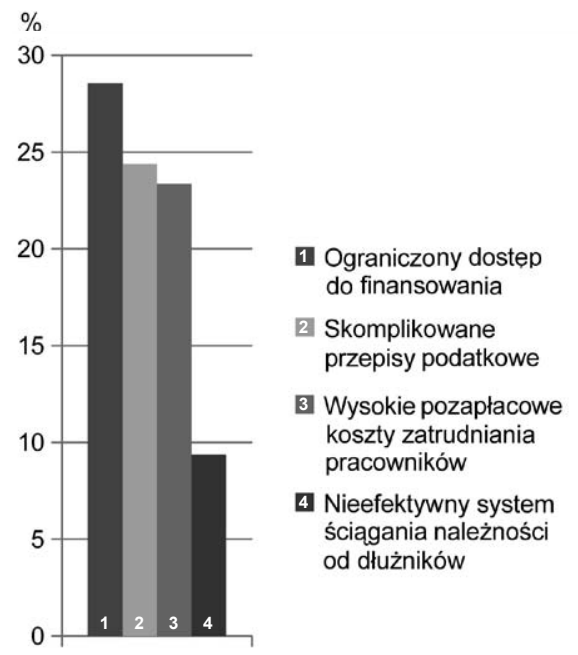

Źródło: DGP, 07.10.2011.

Wśród wskazanych barier kluczowe miejsce zajmuje zła jakość prawa podatkowego (dotyczącego podatków pośrednich i bezpośrednich) oraz koszty stosowania prawa podatkowego. W opinii małych i średnich przedsiębiorstw istniejący w Polsce system podatkowy, jak i wysokość podatków, tworzą poważne bariery w rozwoju MŚP i wpływają na ich sytuację ekonomiczną (Chądrzyński, 2007: 130). Niepokojący może być fakt, że przedsiębiorcy mniej obawiają się konkurencji ze strony szarej strefy niż obowiązujących podatków oraz liczby ich zmian. Również badania przeprowadzone przez Tax Care i Idea Bank wskazują, iż oprócz ograniczonego dostępu do finansowania działalności gospodarczej największą barierą administracyjną są właśnie nieprecyzyjne i skomplikowane przepisy podatkowe. Wskazało na nie ponad $24 \%$ ankietowanych przedsiębiorców. Autor w tym miejscu pragnie zwrócić uwagę na fakt, iż przepisy podatkowe - i nie tylko - tworzone są w większej części przez polityków, którzy niekoniecznie muszą się na nich znać. Owszem, ustawy niejednokrotnie są przygotowywane przez zespół specjalistów czy naukowców, jednakże ostateczny kształt przepisy uzyskują w parlamencie. Niestety, brak profesjonalizmu i wiedzy doprowadził do takiej właśnie sytuacji, że część przepisów jest nienajlepszej jakości.

Warto w tym miejscu wskazać na nieprofesjonalne działania ministra finansów. A chodzi o podwyższenie stawki podatku od towarów i usług na określony czas, jak i na nieuregulowane sprawy z samochodami wykorzystywanymi w działalności gospodarczej. Na okres 2 lat został wprowadzony przepis uniemożliwiający odliczanie VAT od użytkowanych samochodów osobowych i tych z „kratką"2. Minister tłumaczył to potrzebą zbilansowania budżetu państwa. Dziś wydaje się - a wręcz można tak twierdzić - że miało to spowodować zwiększenie docho-

\footnotetext{
${ }^{2}$ Okres ten niestety z końcem 2012 r. został przedłużony na rok następny, czyli 2013. Bazując na swoim doświadczeniu, autor przypuszcza, że kwestie te nie zostaną uregulowane także w następnym roku z uwagi na sytuację budżetu państwa. Proces ten może jedynie przyspieszyć ewentualna „groźba” nałożenia kar na Polskę przez Komisję Europejską.
} 
dów budżetu kosztem przedsiębiorców. Teraz docierają do podatników informacje, że Ministerstwo Finansów chce zmienić przepisy - nie tylko podatkowe, ale i ruchu drogowego - aby w ogóle wyeliminować możliwość odliczania VAT od zakupów związanych z użytkowaniem takich samochodów. Takie działania nie wpływają pozytywnie na odbiór tworzonych przepisów i nie zwiększają ogólnego zaufania do państwa.

Polska należy do krajów o wysokiej relacji składek płaconych przez pracowników i pracodawców na świadczenia społeczne do PKB. Pozapłacowe koszty pracy, tzw. klin podatkowy, stanowią w Polsce blisko $40 \%$ obciążeń związanych z zatrudnianiem pracownika. O ich wysokości decydują podatki dochodowe oraz składki na ubezpieczenie społeczne opłacane zarówno przez pracodawców, jak i przez zatrudnionych. W konsekwencji wynagrodzenie otrzymywane przez przeciętnego polskiego pracobiorcę stanowi jedynie $60 \%$ kosztów, jakie pokrywa pracodawca (Rosiński, 2008: 86-87). Jednak na pozytywną opinię zasługuje fakt, iż Polska znalazła się w grupie państw, które w ciągu ostatniej dekady najbardziej zredukowały obciążenia nakładane na pracę. Między 2000 a 2010 r. zmniejszyły się one z 41,9\% do 34\%. Duży wpływ na ten wynik miało obniżenie składki rentowej w 2007 r. oraz redukcja i wprowadzenie dwóch stawek podatku dochodowego (PIT) w 2009 r. Największy udział w klinie podatkowym w Polsce miały ubezpieczenia społeczne i zdrowotne, gdyż stanowią one ponad $30 \%$ łącznego kosztu pracy. Natomiast wielkość obciążenia podatkiem dochodowym zależy od osiągniętego dochodu i kształtuje się od zaledwie kilku procent przy najniższym dochodzie do kilkudziesięciu procent po przekroczeniu II i III progu podatkowego. Reformy systemów podatkowych z lat 2008-2009 pozwoliły wyraźnie obniżyć pozapłacowe koszty pracy także w takich państwach, jak: Turcja, Czechy, Finlandia, Słowacja czy Luksemburg.

Składki w Polsce w relacji do podatków są dość wysokie, co istotnie zwiększa koszty pracy, osłabia popyt na pracę i zapewne przyczynia się do wysokiego bezrobocia. Składki na ubezpieczenie społeczne są podstawowym czynnikiem kosztów pracy. Postulowane obniżenie składki, co zresztą częściowo się stało poprzez obniżenie składki rentowej, miało zwiększyć podaż pracy, niestety jednocześnie zmniejszałoby środki dostępne na wypłatę świadczeń. Dylemat ten bardzo ostro występuje w Polsce i jak do tej pory nie został rozwiązany ${ }^{3}$.

Mnogość aktów prawnych, rozporządzeń, niejednokrotnie niejasnych, wymagających wykładni, stanowi poważną trudność dla przedsiębiorców, szczególnie drobnych. Podobny problem dotyczy regulacji prawnych. Poważną trudnością dla prowadzących działalność gospodarczą są często zmieniające się przepisy oraz utrudniony dostęp do tekstów obowiązujących rozwiązań prawnych. Zmusza to niejednokrotnie właścicieli firm do zatrudniania bądź korzystania z usług specjalistów z dziedziny prawa czy księgowości, co z kolei powoduje wzrost, często znaczny, kosztów prowadzenia działalności gospodarczej (Tomkiewicz, 2005).

Dla ponad 70\% MŚP bardzo istotną barierą rozwoju jest brak przejrzystości i jednoznaczności podatków pośrednich (VAT i akcyza) oraz podatków od działalności gospodarczej (CIT, PIT). Właściciele małych i średnich przedsiębiorstw uważają, że brak czytelności w regulacjach podatkowych zwiększa ryzyko działalności gospodarczej i generuje koszty, które w sposób nieuzasadniony obciążają ich działalność, zmniejszając tym samym konkurencyjność. Ma to oczywiście duże znaczenie, bowiem przepisy regulujące opodatkowanie działalności niejednokrotnie są umieszczane w kilku aktach prawnych. Wywołuje to sytuację, w której podatnik, jak i urzędnik skarbowy, muszą sięgać do kilku przepisów lub nawet aktów prawnych, aby

\footnotetext{
${ }^{3}$ Doprowadził w końcu do ostrej dyskusji na temat sensu istnienia dwóch filarów ubezpieczeniowych, tj. OFE i ZUS, i wprowadzono zmiany w tym zakresie. Ponadto, aby ratować budżet państwa oraz fundusz rentowy w ZUS, od 2012 r. podniesiono wysokość składki rentowej płaconej przez pracodawcę.
} 
ustalić obowiązki związane z opodatkowaniem. Często wskazuje się też na niekompetencję pracowników administracji podległej ministrowi finansów. Jednak sami pracownicy też mają kłopoty ze stosowaniem ciągle zmieniającego się prawa. Szanowny Czytelnik zapewne nie wie, że zmiany w przepisach są dokonywane bez konsultacji z pracownikami bezpośrednio zajmującymi się stosowaniem przepisów podatkowych. Autor, jak i jego współpracownicy w swojej ponad 10-letniej karierze urzędnika tylko raz lub dwa razy został zapytany o opinię na temat projektu aktu prawnego. Niestety było to tylko rozporządzenie, a nie ustawa. W przypadku tworzenia ustaw urzędnicy bezpośrednio stosujący przepisy, spotykający się z podatnikami, od których niejednokrotnie słyszą potrzebę wprowadzenia zmian, nie biorą w tym procesie bezpośredniego udziału. A być może zebrane i uwzględnione opinie na temat przepisów pozwoliłyby stworzyć w miarę dobrze prosperujące prawo.

Przepisy podatkowe zawarte w ustawach są i były zmieniane wielokrotnie. Obowiązujące ustawy podatkowe pochodzą nawet z 1983 r. Ze względu na czas obowiązywania najdłużej funkcjonuje ustawa o podatku od spadków i darowizn z 1983 r. (29 lat) oraz ustawa o podatku rolnym z 1984 r. (28 lat). Najkrócej obowiązuje ustawa podatkowa o podatku tonażowym z 2006 r. oraz ustawy uchwalone w 2004 r., tj. ustawa o podatku od towarów i usług oraz ustawa o podatku akcyzowym. Aby lepiej zobrazować czytelnikowi ogrom zmian dokonywanych w przepisach podatkowych, autor dokonał oszacowania liczby zmian w ustawach. Jak zostało to pokazane na poniższej rycinie, podatność poszczególnych ustaw na zmiany nie była jednakowa (ryc. 5$)^{4}$.

Na czołowe i mało chlubne miejsce wysuwają się pod tym względem ustawy o podatkach dochodowych. Ustawa o podatku dochodowym od osób fizycznych była w ciągu 20 lat zmieniana 180 razy, zaś ustawa o podatku dochodowym od osób prawnych była zmieniana 137 razy (Kosikowski, 2007: 127). Dla porównania można wskazać ustawę o podatku od spadków i darowizn, która obowiązuje od ponad ćwierć wieku i była zmieniana około 20 razy czy podatek rolny, który zmieniono 19 razy. Ale już ustawę o podatku akcyzowym zmieniano 16 razy od 2008 r. Przepisy Ordynacji podatkowej od 1997 r. zmieniano ponad 100 razy. Wskazanie innych niechlubnych rekordów również nie sprawia trudności. Można znów wskazać ustawę o podatku dochodowym od osób fizycznych, która w samym tylko roku 2005 była zmieniana aż 18 razy. Podobne wyniki miała ustawa o podatku dochodowym od osób prawnych, którą w 2004 r. nowelizowano 16 razy (w porównaniu do 15 zmian w 1997 r.) $)^{5}$. Można by rzec w tym miejscu, że kilka zmian - od jednej do trzech czy czterech - to symboliczne wyniki. Jednak jeśli spojrzeć na to od strony zasad tzw. przyzwoitej legislacji, są to wyniki niedopuszczalne. Próbę oszacowania liczby zmian dokonywanych w przepisach podjął także PKPP Lewiatan. Jak wynika z dokonanych obliczeń od 1 maja 2004 r. w Polsce dokonano ponad 12400 zmian w przepisach podatkowych, uchwalając jednocześnie 378 nowelizacji ustaw podatkowych.

Prawie $60 \%$ przedsiębiorców zapytanych o najbardziej uciążliwe dla nich przepisy prawa wskazuje przede wszystkim ustawę o VAT oraz ustawę o PIT i CIT. Zaznaczyć w tym miejscu należy, iż począwszy od 2011 r. stawka podatku od towarów i usług należy do najwyższych w Europie, bowiem wynosi ona $23 \%$. Barierą dla prawie $70 \%$ przedsiębiorców też jest wysokość stawki podatku dochodowego. Co prawda od 2004 r. obowiązuje w Polsce 19\% podatku od

\footnotetext{
${ }^{4}$ Autor pragnie w tym miejscu zaznaczyć, iż na rycinie przedstawione są zmiany ogłaszane w dziennikach ustaw, a nie poszczególne, jednostkowe przepisy, bo tych zmian było zdecydowanie więcej.

${ }^{5}$ Choć należy także w tym miejscu wskazać na ponad 40 zmian przepisów dotyczących ustawy o podatku od towarów i usług (wraz z przepisami znajdującymi się w rozporządzeniach), które wprowadzono $\mathrm{w}$ pierwszej połowie $2011 \mathrm{r}$.
} 
Ryc. 5. Liczba zmian w ustawach podatkowych do $2011 \mathrm{r}$.

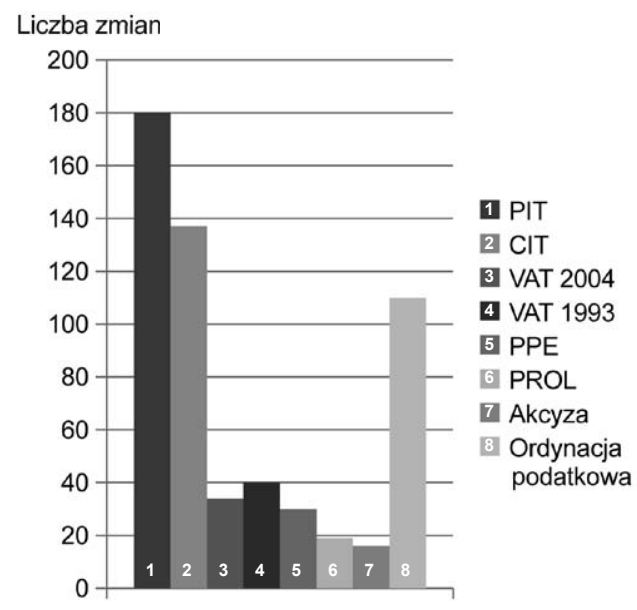

Źródło: opracowanie własne na podstawie dzienników ustaw oraz wskazanych ustaw.

działalności gospodarczej, ale nie jest to już poziom konkurencyjny. W takich krajach, jak Irlandia, Cypr, Estonia, Łotwa, Litwa czy Węgry, stawka podatku CIT jest niższa niż w Polsce (Zagórska, 2011: 2). Wzrost gospodarczy osiągany w tych krajach (poza Węgrami, których problemy tkwią nie w podatkach, a w finansach publicznych w ogóle) pozwala na postawienie tezy o zależności między niskim poziomem danin publicznych a wysokim tempem wzrostu PKB.

Dodatkowo wiele problemów związanych z rozliczaniem VAT rodzą: skomplikowana konstrukcja ustawy czy niejasna klasyfikacja towarów i usług a w związku z tym trudności w określeniu stawki podatku. Wskazać również w tym miejscu należy na moment powstania zobowiązania podatkowego jako jednej z przyczyn kłopotów finansowych przedsiębiorców i trudności w rozliczeniach z budżetem państwa. A to dlatego, że już w chwili sprzedaży i wystawienia faktury przedsiębiorcy są zobowiązani do odprowadzenia podatku od towarów oraz usług, nawet jeżeli kupujący zwleka z płatnością lub nie uregulował jej w ogóle. Wprawdzie ustawa o VAT przewiduje możliwość skorzystania z tzw. „ulgi na złe długi”, pozwalającej odzyskać zapłacony do urzędu skarbowego podatek po wystawieniu faktur, które nie zostały uregulowane. Jednak próba odzyskania podatku podnosi stopień skomplikowania rozliczeń podatkowych.

Nie można w tych dywagacjach pominąć przepisów regulujących podatki dochodowe. $\mathrm{Na}$ wysokość podatku ma wpływ kilka czynników. Najważniejsze z nich to: stawka podatku oraz zakres opodatkowania. Dużą rolę odgrywają także: konstrukcja przychodów, elastyczny katalog kosztów uzyskania przychodów, wysokość odpisów amortyzacyjnych oraz możliwość rozliczania strat z lat ubiegłych. Różnica pomiędzy nominalną a efektywną stawką podatku zależy od możliwości wykorzystania przez podatników ulg i odliczeń. Na znaczne obciążenia podatkowe wpływała duża liczba nierentownych przedsiębiorstw, a także rygorystycznie określone kryteria przyznawania ulg inwestycyjnych w okresach ich obowiązywania. I znów w tym miejscu można wskazać na niezgodne z prawem wspólnotowym stanowisko ministra finansów, który twierdzi, iż przedsiębiorca działający w specjalnej strefie ekonomicznej nie ma prawa do rozliczenia straty z tytułu prowadzonej działalności gospodarczej. Powoduje to oczywiście, iż 
w tej sytuacji przedsiębiorca działający w specjalnej strefie ekonomicznej znajduje się w gorszym położeniu niż przedsiębiorcy działający poza nią ${ }^{6}$.

Wpływ na nieefektywne działania przedsiębiorstw opodatkowanych podatkiem dochodowym od osób prawnych mają różnice w obliczaniu dochodów do celów rachunkowych i do celów podatkowych. Ustawa o rachunkowości nakłada na podmioty gospodarcze obowiązek ujednoliconego sposobu prowadzenia ksiąg rachunkowych oraz sporządzania bilansu i rachunku wyników według określonych zasad. Zaś ustawa o podatku dochodowym od osób prawnych szczegółowo określa sposób obliczania dochodu stanowiącego podstawę opodatkowania. W ustawie wskazane są także pozycje przychodów i kosztów, które należy w tym rachunku uwzględnić.

Poza tym występuje dużo różnic między ujęciem księgowym a ujęciem podatkowym poszczególnych pozycji, zwłaszcza po stronie kosztów. Do kosztów przeznaczonych na cele podatkowe nie wlicza się zapłaconych przez firmę odszkodowań, wydatków związanych z naruszeniem przepisów o ochronie środowiska czy rezerw tworzonych w ciężar kosztów. Katalog ten jest dość duży. Zweryfikowany dochód przeznaczony na cele podatkowe jest zazwyczaj wyższy niż dochód wykazywany w księgowości. Uregulowania takie zmuszają firmy do poszukiwania kosztów, które niejednokrotnie są nieefektywne z punktu widzenia rachunkowości, ale przynoszą efekty do celów podatkowych.

Ustawy o podatku dochodowym od osób fizycznych i prawnych zawierają katalogi wydatków, które w rozumieniu ustawodawcy nie stanowią kosztów uzyskania przychodów. Artykuły wykluczające poszczególne wydatki z kosztów uzyskania przychodów są tak rozbudowane i niejasne, że już stają się nieczytelne nie tylko dla zwykłego podatnika, ale i dla specjalistów. Niepokojące jest również to, że katalog ten cały czas jest poszerzany. Niestety nie idzie za tym próba usystematyzowania czy wprowadzenia jakiejś logicznej struktury przepisów. Po prostu wprowadza się kolejne zmiany i już. Taka niejasność przepisów prowadzi niejednokrotnie do konfliktów na linii urząd skarbowy - podatnik, gdzie to ten drugi zobowiązany jest wykazać, iż poniesione wydatki są prawidłowe i stanowią koszty uzyskania przychodów. Niekiedy konflikt ten musi rozstrzygnąc sąd ${ }^{7}$.

W tych warunkach w gospodarce można zaobserwować specyficzną ewolucję systemu podatkowego. Przepisy podatkowe wielokrotnie były zmieniane. Zmiany te były nakierowane na coraz większą restrykcyjność i szczelność systemu podatkowego, szczególnie w zakresie VAT oraz podatku dochodowego od osób fizycznych. Jednak nie miały one ustabilizować gospodarki ani w średnim, ani tym bardziej w długim okresie. W większości związane były z cyklem wyborczym, i, jak wyżej wspomniano, z obietnicami politycznymi, a większość zmian dokonywanych w podatkach i parapodatkach miała charakter doraźny, a nie zaplanowany.

Można więc dojść do wniosków, że system podatkowy działa nieprawidłowo, a stan prawa podatkowego w Polsce jest niski, gdyż o jego kształcie decydują osoby niemające ku temu odpowiedniej wiedzy i doświadczenia. Jak twierdzi M. Kosek-Wojnar, takie działania przybierają formę radosnej twórczości, tak rządu, jak i parlamentarzystów (Kosek-Wojnar, 2012: 176). Nie można zapomnieć, że parlamentarzystów w karkołomnych zmaganiach z prawem podatkowym wspiera minister finansów. Dlatego ważne jest, aby ministrowie finansów i osoby im

\footnotetext{
${ }^{6}$ Warto było wspomnieć o tym problemie, bowiem w pewnym sensie wypacza on sens istnienia specjalnych stref ekonomicznych. Jednak szczegółowe jego omówienie wykracza poza ramy niniejszego opracowania.

${ }^{7}$ Oczywiście powyższe przykłady nie wyczerpują tematu i stanowią pewien zalążek do dalszych badań na temat ademptoryzacji polskiego systemu podatkowego w Polsce.
} 
doradzające zrozumiały, że podatnicy nie mogą być zaskakiwani zmianami. Raz dane słowo nie powinno być zmieniane, tak jak dzieje się to dziś.

Powyższe opinie potwierdzają także raporty przygotowywane przez Ministerstwo Gospodarki. Wskazano w nich, iż przepisy prawa podatkowego są oceniane najgorzej. Przedsiębiorcy uregulowania prawne w zakresie podatków oceniają jako najgorsze w obszarze prowadzenia działalności gospodarczej. Według Ministerstwa Gospodarki negatywnie o podatkach wypowiedziało się $44 \%$ respondentów, w tym 11\% przedsiębiorców oceniło przepisy jako bardzo złe (Przedsiębiorczość..., 2010: 118).

\section{Zakończenie}

Stan prawa podatkowego w Polsce budzi wiele kontrowersji, zarówno wśród praktyków, jak i teoretyków prawa podatkowego. Faktem jest skomplikowane i niekonsekwentne tworzenie prawa podatkowego. Taki stan rzeczy jest m.in. następstwem tego, że o kształcie systemu oraz prawa podatkowego, tak jak napisano wcześniej, decydują siły polityczne, i to, że nasi delegaci do parlamentu mają ogromny wpływ na zatwierdzanie oraz wprowadzanie w życie nowych koncepcji prawa podatkowego. Niewątpliwie opracowanie i wdrożenie właściwego systemu podatkowego nie jest sprawą łatwą, ale z pewnością nie można tego robić metodą prób i błędów. Niestety, na taką taktykę wskazuje analiza różnych zmian przeprowadzonych w okresie 1989-2012, a w szczególności dane przedstawione w niniejszym artykule. Częste nieprzemyślane koncepcje określonych rozwiązań prawnych podlegały poprawie dopiero w trakcie ich realizacji, i to w tempie niepozwalającym na pełną ocenę praktycznych efektów opodatkowania w sferze gospodarczej i prawnej.

Polski system podatkowy wykazuje charakterystyczną cechę współczesnych systemów podatkowych, czyli brak stabilności. Stabilność, z którą można powiązać także akceptowalność podatków, spełnia w znacznej mierze pozostałe zasady podatkowe i dla twórców systemu podatkowego dążenie do takiego stanu rzeczy powinno być priorytetem. Ciągłe zmiany w ustawach podatkowych, niejednokrotne wprowadzanie nieracjonalnych ulg i innych przywilejów coraz bardziej komplikowały poszczególne podatki. To wszystko powodowało ciągłe poprawianie i doprecyzowywanie przepisów podatkowych, i - jak już powiedziano wcześniej - prowadziło do niestabilności systemu podatkowego. Oczywiście należy w tym miejscu jasno powiedzieć, że system podatkowy musi podlegać ewolucji, ze względu na zmieniające się warunki gospodarcze czy społeczne. Jednak uproszczenie przepisów spowoduje ograniczenie możliwości manipulacji podatkowych, a zarazem usprawni funkcjonowanie podatników. Zjawisko to można zaobserwować w Polsce, bowiem zmiany podatkowe uchwalane są w każdym roku podatkowym.

Mówiąc o stabilności opodatkowania, należy podkreślić fakt, iż uproszczenie przepisów podatkowych zmniejszy koszty ich stosowania tak po stronie podatników, jak i aparatu skarbowego. A to przyczyni się do większej jego efektywności. Uproszczenie poszczególnych podatków zmniejszy obciążenia podatkowe oraz usprawni rozliczenia na drodze podatnik urząd skarbowy. Stabilność i przejrzystość przepisów podatkowych umożliwiają długofalowe planowanie, ponieważ podatnicy nie są zaskakiwani ciągłymi zmianami w przepisach.

Trudno wypracować jednoznaczne kryterium oceny zarówno konstrukcji teoretycznych, jak i konkretnych rozwiązań praktycznych. Obywatele, w tym naukowcy, uogólniają często swoją wiedzę na temat funkcjonowania systemu podatkowego przez pryzmat doświadczeń z urzędem skarbowym. Takie podejście i postawy niejednokrotnie zamazują szerszą perspektywę spojrzenia na system podatkowy jako na instrument, który może wspierać długofalowy, zrównoważony rozwój kraju. Ważnym wyznacznikiem każdego systemu podatkowego, jak wcześniej o tym pisano, jest także jego stabilność, gdyż nadmierna zmienność wprowadza dodatkowy element 
ryzyka, przy którym inwestorzy i przedsiębiorcy nie mogą podejmować decyzji racjonalnych w długim horyzoncie czasowym. To z kolei przekłada się na funkcjonowanie i rozwój całej gospodarki. W tym kontekście istotne jest tworzenie jak najszerszej bazy podatkowej warunkującej poziom stawek podatkowych i pozwalającej działać wszystkim podmiotom w takim samym otoczeniu zewnętrznym (zbyt wysokie podatki oraz skomplikowanie przepisów powodują przenoszenie części działalności do szarej strefy).

W obecnych warunkach należy i powinno się kontynuować wdrażanie już zapoczątkowanych rozwiązań w zakresie systemu podatkowego polegające na:

- unowocześnieniu i uproszczeniu systemu podatkowego,

- redukcji stawki podstawowej w podatku od towarów i usług, a nie jej podnoszeniu, jak to czynił rząd od 2011 r.,

- poszerzeniu bazy podatkowej w sposób zgodny z zasadami podatkowymi (czyli objęciu opodatkowaniem nowych grup podatników), a nie zgodnie z zasadą, że zwiększamy obciążenia tym, którzy już płacą,

- harmonizacji przepisów podatkowych z regulacjami Unii Europejskiej,

- uporządkowaniu przepisów ustaw podatków dochodowych pod względem wydatków niestanowiących kosztów uzyskania przychodów,

- zaprzestaniu prowadzenia polityki ograniczania możliwości odliczania podatku VAT naliczonego od coraz większej liczby towarów i usług,

- uporządkowaniu kwestii zakupów samochodów firmowych oraz odliczania od ich użytkowania podatku VAT,

- doprowadzeniu do ujednolicenia przepisów podatkowych z przepisami o rachunkowości.

\section{Literatura}

Arent, A. (2007). Ocena wybranych warunków stosowania rozwiązań podatkowych dla przedsiębiorców. W: J. Głuchowski, A. Pomorska, J. Szołno-Koguc (red.), Podatkowe i niepodatkowe źródła finansowania zadań publicznych. Lublin: Wydawnictwo KUL.

Bank Światowy \& PricewatehuseCoopers (2010). Paying Taxes 2010. The globar picture. Pozyskano z: http://www.doingbusiness.org/.

Chądrzyński, M. (2007). Główne bariery rozwoju i funkcjonowania małych i średnich przedsiębiorstw na obszarach wiejskich województwa łódzkiego. Przedsiębiorczość - Edukacja, 3.

Kamińska, W. (2006). Wpływ procesów transformacji na rozwój małych firm prywatnych w Polsce. Przedsiębiorczość - Edukacja, 2.

Kosikowski, C. (2007). Podatki. Problem władzy i podatników. Warszawa: Wydawnictwo LexisNexis.

Kosek-Wojnar, M. (2012). Zasady podatkowe w teorii i praktyce. Warszawa: Wydawnictwo PWE.

Ministerstwo Gospodarki. (Lipiec 2010). Przedsiębiorczość w Polsce. Warszawa.

Ostaszewski, J. (red.). (2010). Finanse. Warszawa: Wydawnictwo Difin.

Raport Banku Światowego Doing Business 2008-2011.

Rosiński, R. (2008). Polski system podatkowy. Poszukiwanie optymalnych rozwiązań. Warszawa: Wydawnictwo Difin.

Starczewska-Krzysztoszek, M. (2008). Konkurencyjność sektora MŚP 2007. Raport z badań, PKPP Lewiatan, Warszawa.

Szczodrowski, G. (2003). Polski system podatkowy. Strategia transformacji. Gdańsk: Wydawnictwo UG.

Szołno-Koguc, J. (2000). Reforma polskiego systemu podatkowego 1990-1995: założenia a realizacja, Lublin: Wydawnictwo UMCS. 
Tomkiewicz, J. (2005). Polityka fiskalna a proces formowania się kapitału w gospodarkach posocjalistycznych. W: J. Tomkiewicz (red.), Finanse publiczne a wzrost gospodarczy. Warszawa: Wydawnictwo WSPiZ im. L. Koźmińskiego.

Zagórska, J. (2011). Bariery rozwoju matych i średnich przedsiębiorstw. Administracyjno-prawne aspekty prowadzenia działalności gospodarczej, PARP, Warszawa.

ZPP. (2011). Raport 2012 - Warunki prowadzenia firm w Polsce, Warszawa: Centrum im. A. Smitha.

\section{Źródla internetowe}

www.radapodatkowa.pl

Piotr Możyłowski, dr nauk ekonomicznych. Wyższa Szkoła Nauk Społecznych i Technicznych w Radomiu. W latach 2001-2013 pracował w Pierwszym Urzędzie Skarbowym w Radomiu na stanowisku inspektora w Dziale Egzekucji Administracyjnej. Od 2012 r. pracuje jako wykładowca w Wyższej Szkole Nauk Społecznych i Technicznych w Radomiu oraz Wyższej Szkole Handlowej im. S. Batorego w Piotrkowie Trybunalskim. Zainteresowania badawcze koncentrują się na obciążeniach publicznoprawnych MMŚP, barierach podatkowych prowadzenia działalności gospodarczej oraz ich wpływu na wielkość szarej strefy. W kręgu zainteresowań oprócz powyższego pozostaje zarządzanie należnościami oraz windykacja.

Piotr Możyłowski, PhD in Economic Science, Academy of Social and Technical Sciences in Radom. In the years 2001-2013 has worked in the First Revenue Office in Radom as an inspector in the Department of Enforcement Administration. From 2012, works as a lecturer at the School of Social Sciences and Technology in Radom and the School of them. S. Batory Piotrkow. Research interests are focused on public duty of SME sector, tax barriers to economic activity and its impact on the size of the shadow economy. In addition to the above, interest remain to debt management and debt recovery.

Adres/Address: Wyższa Szkoła Nauk Społecznych i Technicznych w Radomiu ul. Wodna 13/21, 26-600 Radom, Polska e-mail: piotr.mozylowski@gmail.com 